Katarzyna Barańska

Uniwersytet Jagielloński, Wydział Zarządzania i Komunikacji Społecznej, Instytut Kultury

Arkadiusz Jełowicki

Muzeum Narodowe Rolnictwa i Przemysłu Rolno-Spożywczego w Szreniawie

Mariola Tymochowicz

Uniwersytet Marii Curie-Skłodowskiej w Lublinie, Instytut Nauk o Kulturze

\title{
Pierwsza edycja Konkursu PTL im. Antoniego Kaliny w kategorii wystawienniczej
}

Idea zorganizowania konkursu Polskiego Towarzystwa Ludoznawczego obejmującego działalność wystawienniczą nie jest zupełnie nowa, ale dopiero w 2020 r. ostatecznie przybrała realny kształt. Opracowaniem propozycji regulaminu wydarzenia zajęła się Katarzyna Majbroda (wiceprezeska PTL i prezeska z Oddziału PTL we Wrocławiu). Po jego przyjęciu przez Zarząd Towarzystwa Konkurs otrzymał także oficjalną nazwę i patrona: „Nagroda im. Antoniego Kaliny”, czyli założyciela pierwszego polskiego etnograficznego towarzystwa. W Konkursie przewidziano trzy kategorie: „najciekawsza publikacja”, „najciekawsza wystawa” i „najciekawsze wydarzenie”, oczywiście wszystkie powinny być związane z tematyką etnologiczną lub antropologiczną. Równolegle powstały trzy zespoły jurorskie dla każdej z trzech wspomnianych kategorii. Do oceny wystaw swój udział zgłosili: Katarzyna Barańska (Członek ZG, PTL O/Kraków, badaczka zagadnień muzealnictwa w Polsce, UJ w Krakowie), Arkadiusz Jełowicki (Sekretarz ZG, PTL O/Poznań, kustosz w Muzeum Narodowym Rolnictwa i Przemysłu Rolno-Spożywczego w Szreniawie) i Mariola Tymochowicz (skarbnik ZG, PTL O/Lublin, kustosz Muzeum Narodowego w Lublinie, UMCS w Lubli- 
nie). Ostatecznie w inauguracyjnej edycji nadesłano dziewięć zgłoszeń do Konkursu. W szranki stanęły następujące wystawy, które miały miejsce w ubiegłym roku:

1. „Dokumenty osobiste jako źródło wiedzy o wsi”; organizator: Instytut Rozwoju Wsi i Rolnictwa Polskiej Akademii Nauk, Polskie Wydawnictwo Rolnicze Sp. z o.o., Centralna Biblioteka Rolnicza im. Michała Oczapowskiego; kuratorka: dr Sylwia Michalska.

2. „Anatomia muzeum. 60 lat Muzeum Etnograficznego w Toruniu”; organizator: Muzeum Etnograficzne im. Marii Znamierowskiej-Prüfferowej w Toruniu; kurator/-ki: Piotr Dąbrowski, Aleksandra Jarysz, Agnieszka Kostrzewa.

3. „Od śmierci nikt się nie wykręci”; organizator: Muzeum Górnośląskie w Bytomiu; kuratorka: Urszula Bracka.

4. „Wzornik. Szycie opoczyńskie, łowickie, sieradzkie. Tradycja/trwanie w 100-lecie województwa łódzkiego"; organizator: Muzeum Archeologiczne i Etnograficzne w Łodzi; kuratorka: Alicja Woźniak.

5. „Chłopskie requiem. Zwyczaje pogrzebowe na polskiej wsi”; organizator Fabryka Sztuk; kuratorka: Kamila Gillmeister.

6. „W wiśniewskiej garnkowni pani Wandy”; organizator: Muzeum Mazowieckie w Płocku; kuratorka: Elżbieta Miecznikowska.

7. „Enklawa. Osada Herrnhutów w Gnadenfeld-Pawłowiczkach”; organizator Muzeum Wsi Opolskiej: kuratorka: Elżbieta Oficjalska.

8. „Ty Bambrze!”; organizator: Muzeum Etnograficzne, Oddział Muzeum Narodowego w Poznaniu; kuratorka: Aneta Skibińska.

9. „Podróże wycinanek”; organizator: Muzeum Częstochowskie; kuratorki: Agnieszka Ciuk-Koćwin, Magdalena Matysiak, Ewelina Mędrala-Młyńska.

Wszyscy zgłaszający nadesłali materiały, które zostały określone w Regulaminie konkursu. Członkowie Komisji mieli możliwość zapoznania się z zamieszczonymi w formularzach (dostępne na stronie ptl.info.pl) informacjami dotyczącymi danej wystawy odnoszącymi się do kwestii autorstwa, czasu i miejsca trwania, współpracy podjętej w ramach przygotowywania wystawy i tym podobnymi danymi o charakterze formalnym. Jednakże clou, stanowiące podstawę do ocenienia danej wystawy były opisy i informacje o założeniach wystaw, wzbogacony materiałem ilustracyjnym w postaci fotografii, a także, w niektórych przypadkach, 
filmów dokumentujących wystawę i wydarzenia towarzyszące i nagrań z telewizji i doniesień prasowych.

Członkowie Jury po zapoznaniu się z wszelkimi dostępnymi materiałami spotkali się w celu ustalenia oceny nadesłanych zgłoszeń i wyłonić zwycięzcę. W czasie wcześniejszych konsultacji przyjęto kryteria, według których uważali, że należy oceniać poszczególne wystawy.

Pierwszym, przyjętym kryterium był „Pomysł/idea”. W jego ramach zadano pytania dotyczące motywacji organizatorów do zrobienia wystawy, wyznaczenie głównego celu i założeń wystawienniczych. Jury interesowało, czy Autorzy wystaw nakreślili najważniejsze pytania badawcze, na które starali się odpowiedzieć organizując ekspozycję. Wystawy są okazją do prezentacji wiedzy, poglądów, do zobrazowania odkrytych prawd o świecie i ludziach. Mogą również stanowić istotny wkład w społecznie obecny dyskurs dotyczący trendów i paradygmatów odgrywających w danym momencie rolę w kulturze. Oczywistym wydawało się założenie, że wystawa nie może być zbiorem przypadkowych przedmiotów, ale musi starać się odkryć jakiś sens o człowieku i/lub jego otoczeniu, istotne było na ile Autorzy sformułowali tego typu założenia.

Sposób, w jaki idea wystawy została przedstawiona określono jako „Kreacja/oprawa”. Komisja konkursowa zadała sobie pytanie o to, czy Autorzy potrafili zrealizować merytoryczne cele wystawy i przekazać je publiczności tak, by to było spójne z założeniami, czy widz może odczytać zamierzenia autorów. Brano również pod uwagę warstwę plastyczną i ewentualnie obecność nowatorskich środków przedstawienia ustaleń treściowych. Wystawa nie powinna charakteryzować się brakiem równowagi pomiędzy różnymi formami przekazu treści, nie powinno brakować odpowiednich opisów, ani nie powinno być ich zbyt wiele. Współcześnie należy zwrócić także uwagę na obecność na wystawie środków multimedialnych oraz na to, czy nie są nadmiernie wykorzystywane lub/oraz czy ich obecność wspiera pełny odbiór prezentacji. Oprawa plastyczna powinna służyć wyjaśnianiu założeń ideowych wystawy, równocześnie pełni przecież funkcje estetyczne i ma dostarczać widzowi przyjemności przebywania w odpowiednio skomponowanym otoczeniu.

W ostatnich czasach mówi się wiele o edukacyjnej funkcji muzeów (i galerii), wystawy mają przede wszystkim być nośnikami treści. Z tego powodu kolejnym kryterium, które Komisja rozpatrywała była właśnie „Edukacja”. Członkowie Komisji zastanawiali się czy działania edukacyjne są zapla- 
nowane i celowe, czy znani są adresaci tych działań (np. grupy wiekowe). Ważne były także sposoby podejmowane przez twórców wystaw do przekazywania treści. Uwzględniono i oceniono wysoko nowatorskie sposoby przekazywania wiedzy, kwestie możliwości prowadzenia edukacji przez zabawę (np. wprowadzenie gier planszowych lub innych), podejmowanie interaktywnych zajęć ze zwiedzającymi. Ważne wydawało się również dostrzeżenie ciekawych pomysłów na działania towarzyszące wystawie oraz bogactwo ich celów (edukacja, rozrywka).

Stosunkowo niewiele informacji w materiałach nadesłanych na Konkurs znaleziono w obszarze, który równie ważny we współczesnym muzeum, tzn. „Promocja”. Jest to bowiem ten zakres działalności tego typu instytucji, który niesłusznie bywa niekiedy pomijany przez samych zainteresowanych i sprowadzany czasem wyłącznie do akcji typu plakatowanie. Tymczasem jest to ten rodzaj działalności, którego celem jest realizacja jednej z definicyjnych funkcji muzealnych, to znaczy upowszechniania. Dlatego poza sposobami reklamowania wystawy jury zwracało uwagę na to, w jaki sposób funkcjonowała ona w tradycyjnych i nowych mediach (np. media społecznościowe). Poszukiwano również wiadomości o trwałych śladach wystaw - czyli o wydawnictwach, drukach ulotnych, gadżetach i sposobach ich dystrybuowania. Istotne wydaje się również to, jaka była frekwencja na wystawach oraz dobrze byłoby się dowiedzieć czy organizatorzy wystaw starali się dowiedzieć czegokolwiek na temat odbioru wystawy i treści, których była nośnikiem. Upowszechnianie ma bowiem sens tylko wtedy, gdy spotyka się ze społecznym odzewem.

W wyniku (momentami dosyć burzliwej) dyskusji członkowie komisji zdecydowali się przyznać pierwszą nagrodę wystawie „Wzornik. Szycie opoczyńskie, łowickie, sieradzkie. Tradycja/trwanie w 100-lecie województwa łódzkiego” zorganizowanej w Muzeum Etnograficznym w Łodzi. Autorką zwycięskiej wystawy była Alicja Woźniak, która od lat zajmuje się kwestiami związanymi z dziedzictwem zawartym w stroju, rękodziele i hafcie. Jest znawczynią, której wiedza i doświadczenie gwarantują wysoki poziom merytoryczny podejmowanych problemów badawczych, omawianych przez nią zarówno przez takie medium jakim są wystawy, jak i w licznych publikacjach.

Przedstawienie haftu z trzech regionów: opoczyńskiego, łowickiego i sieradzkiego mogło stać się pretekstem do urządzenia sztampowej i nudnej wystawy. Tak się jednak nie stało, wystawa w sposób rzetelny ukazywała 
zarówno historię haftu, jak i jego współczesność — praktyki i inspiracje. Powstała ona głównie w oparciu o zbiory muzeum łódzkiego, ale też regionalnych z Sieradza, Opoczna i Łowicza oraz uzupełniona o współczesne wyroby twórców ludowych. Stanowiła podsumowanie wcześniej realizowanego projektu Nie tylko petanka... W kręgu haftu dofinansowanego przez Ministerstwo kultury i Dziedzictwa Narodowego. Różnorodność haftów ukazana została na osi czasu od XIX do XXI w., z uwzględnieniem dokonujących się zmian, funkcji, technik i kompozycji. Autorka chciała, jak się wydaje, połączyć w ten sposób przeszłość z teraźniejszością oraz wydobyć cechy wspólne i indywidualne dla danego regionu.

Za szczególnie cenne w tej wystawie członkowie komisji uznali interesujące i inspirujące zaprezentowanie „klasycznej” tematyki etnograficznej w wyjątkowej plastycznie i aranżacyjnie stworzonej przestrzeni. Do przedstawienia haftów w trzech regionach użyte zostały rozmaite media. Na podstawie nadesłanych na Konkurs materiałów można było stwierdzić, że proporcje między obiektami, które wszak są podstawą muzealnych działań, a opisami i użytymi środkami wyrazu były bardzo dobrze wyważone i realizowały edukacyjne cele Wystawy. Członkowie komisji konkursowej zwrócili uwagę na fakt, że odbiorcy aplikacji i filmów towarzyszących (podkreślić należy również obecność wystawy w Internecie) zostali podzieleni według kategorii wiekowych - daje to lepszą możliwość dotarcia do odbiorcy. Jako bardzo ciekawy i ważny pomysł uznano możliwość przygotowania własnego wzoru haftu inspirowanego haftem ludowym z prezentowanych regionów, który z jednej strony może być traktowany jako swoista „pamiątka z wystawy”, z drugiej zaś stanowić zachętę do rozwijania własnych umiejętności w zakresie rękodzieła. Współcześnie można zaobserwować wzrost trendów polegających na tym, że wzmacniają się mody kulturowe na ,slow life”, powrót do natury i prostych form, oraz przede wszystkim odwrotu od przemysłowych form produkcji na rzecz personalizowania produktów i rękodzieła będącego swoistym sposobem na tworzenie zerowych kosztów krańcowych.

Wystawa wraz z bogatą ofertą edukacyjną i popularyzatorską wpisywała się doskonale w odpowiedź instytucji kultury na potrzeby społeczne. Osobny tekst dotyczący zwycięskiej wystawy, dzięki Annie Nadolskiej-Styczyńskiej i przypadkowej koincydencji znajdziecie Państwo w bieżącym numerze ZWAM. 
Zgłoszone do konkursu wystawy niosły ważne treści, które zostały w zróżnicowany sposób przedstawione, jedne bardziej kreatywnie z użyciem wielu różnych środków artystycznych i multimedialnych, inne ze względu na przyjętą formę prezentacji na planszach mniej urozmaicone. Ważne było jednak, że przy każdej z nich podejmowane były różne działań edukacyjnych oraz promocyjne, które znacząco podniosły ich wartość. Konkurs nasz ma na celu nagradzanie wystaw antropologicznych, które nie zawsze są właściwie doceniane. 